\title{
CORRIGENDUM
}

\section{IPA News: In Memoriam - EDWARD (TED) CARNEY - CORRIGENDUM}

D0l:10.1017/S0025100304001598, Published by Cambridge University Press 7 June 2004.

In the obituary of Edward (Ted) Carney in Volume 34, Issue 1 (June 2004), it was stated that he did National Service. His youngest son, David Olof Carney, would like it to be made clear that his father signed up voluntarily and served in the Hussars, and did not do National Service.

\section{Reference}

In Memoriam. 2004. Edward (Ted) Carney. Journal of the International Phonetic Association 34 (1), 123. 